\title{
Toxin production in cyanobacterial mats from ponds on the McMurdo Ice Shelf, Antarctica
}

\author{
B.C. Hitzfeld ${ }^{\mathrm{a}, *}$, C.S. Lampert ${ }^{\mathrm{a}}$, N. Spaeth ${ }^{\mathrm{a}}$, D. Mountfort ${ }^{\mathrm{b}}$, \\ H. Kaspar ${ }^{\mathrm{b}}$, D.R. Dietrich ${ }^{\mathrm{a}}$ \\ ${ }^{a}$ Environmental Toxicology, University of Konstanz, 78457 Konstanz, Germany \\ ${ }^{\mathrm{b}}$ Cawthron Institute, Nelson, New Zealand
}

\begin{abstract}
Cyanobacteria are known to produce hepatotoxic substances, the functional and ecological role of these toxins, however, remains largely unclear. Toxic properties of cyanobacteria collected in Antarctica were investigated to determine whether toxin-producing species can also be found under these environmental conditions. Samples were collected from meltwater ponds on the McMurdo Ice Shelf, Antarctica in the summers of 1997 to 1999. These ponds are colonized by benthic algae and cyanobacterial mats. Oscillatoriales, Nodularia sp., and Nostoc sp. constituted the major taxa in freshwater ponds, while Nostoc sp. was missing from brackish and saline ponds. Samples were taken from either floating, submerged or benthic mats, and extracted for in vitro toxicity testing. The presence of toxins was determined by the phosphatase-inhibition assay and by high performance liquid chromatography. The cytotoxic properties of the extracts were investigated in hepatocytes determining 3-(4,5-dimethylthiazol2-yl)-2,5-diphenyl-tetrazolium bromide metabolism and trypan blue dye exclusion. The results show that all cyanobacterial extracts display phosphatase-inhibiting activity, of which approximately half had significantly greater than $50 \%$ inhibiting activity. The presence of nodularin and microcystin-LR was established by high performance liquid chromatography. Cytotoxic properties, independent of the phosphatase inhibiting activity, were also detected. Toxic strains of cyanobacteria can therefore also be found in Antarctica and this finding may lead to further insight into potential ecological roles of cyanobacterial phosphatase inhibiting toxins.
\end{abstract}

\footnotetext{
* Corresponding author. Tel.: +49-7531-884105; fax +49-7531-883170.

E-mail address: Bettina.Hitzfeld@uni-konstanz.de (B.C. Hitzfeld).
} 


\section{Introduction}

The Ross Sea region, Antarctica, contains a remarkably diverse spectrum of aquatic and semi-aquatic environments, despite the extremely low temperatures prevailing over most of the year. Habitats range from dilute meltwater and hypersaline ponds, ice shelf and glacier pools to mesotrophic and ultraoligotrophic lakes (Vincent and James, 1996). An extensive meltwater system is produced in the ablation zone of the McMurdo Ice Shelf, in the northwest of the Ross Ice Shelf, where a $1500-2000 \mathrm{~km}^{2}$ region of marine and moraine sedimentcoated ice is to a large extent covered by water at the end of the austral summer season. This interconnected meltwater system contains a type of topography called "undulating ice", which is covered by a $10-20 \mathrm{~cm}$ layer of sediment and shows a variation in surface relief of up to $20 \mathrm{~m}$ (Howard-Williams et al., 1990). The hollows are frequently occupied by ponds and lakes ranging in size from 1 to $30,000 \mathrm{~m}^{2}$. Pond chemistry is varied due to different ages of the ponds and due to sea water intrusions and lenses of mirabilite $\left(\mathrm{Na}_{2} \mathrm{SO}_{4}+10 \mathrm{H}_{2} \mathrm{O}\right.$; Howard-Williams et al., 1989). A second type of environment found in this region is an estuary, a flat area of interconnected ponds exposed to the tide (one per day) of McMurdo Sound and thus to sea water. Algal mats dominated by cyanobacteria, but also containing diatoms and planktonic flagellates, make up a large part of the biomass in these summer meltwater ponds (Howard-Williams et al., 1989). While the environment of the "undulating ice" is characterized by a broad range in salinities and a greater diversity of taxa, the estuary shows less variation in salinities and less taxa in the algal mats.

Cyanobacteria from many regions around the world have been shown to produce toxins. These toxins can be cyclic peptides such as the microcystins and nodularins, alkaloids such as anatoxin and the saxitoxins, cylindrospermopsin or lipopolysaccharides (Sivonen et al., 1989; Humpage et al., 1994; Rinehart et al., 1994; Ueno et al., 1996a). The effects of the toxins on mammals and fish range from skin irritation, acute and chronic liver damage, including tumor promotion, to neurological symptoms (Carmichael, 1997). Microcystins and nodularins act by inhibiting protein phosphatases which leads to hyperphosphorylation of cellular proteins such as cytokeratin 8 and 18 (Eriksson et al., 1990; MacKintosh et al., 1990). Largely unknown is the physiological or ecological role these toxins play. Even though eutrophication of water bodies has been implicated in toxin synthesis (Skulberg et al., 1984), the environmental conditions under which cyanobacteria produce toxins remain largely unclear. The functional roles of these toxins for cyanobacteria are also still uncertain. They have been suggested to include defense mechanisms against grazers or to provide an ecological advantage over algae (allelopathy; Christoffersen, 1996), but not over other cyanobacterial species (Shi et al., 1999), to regulate endogenous protein phosphatases (Shi et al., 1999) or even as storage substances (Carmichael, 1997).

This study was conducted in the austral summers (i.e. December-January) 1997-1999 in about 20 sample sites located both in the "undulating ice" region and in an estuary just south of Bratina Island, an area of very slow ice movement 
between the Brown Peninsula and Black Island. The paper shows that cyanobacteria in Antarctica, like their temperate counterparts, produce phosphatase inhibiting and cytotoxic toxins. High toxin content was usually found in cyanobacterial mats containing Nodularia sp. and Oscillatoriales sp. in brackish or saline environments.

\section{Materials and methods}

\subsection{Samples and sample sites}

Samples of cyanobacterial mats were collected in December 1997, January 1998 and January 1999 from meltwater ponds on the McMurdo Ice Shelf just south of Bratina Island $\left(78^{\circ} 00^{\prime} \mathrm{S}, 165^{\circ} 30^{\prime} \mathrm{E}\right)$ from undulating ice regions ("around $\mathrm{P} 70^{\prime \prime}$ and "secondary mat collecting area") and from the estuary ("Bratina Island Estuary"). Most ponds were ice-free at the time of sampling while some, especially fresh water ponds, were covered with ice. Transects were taken in two ponds: horizontal $(\mathrm{H} 2, \mathrm{H} 4)$ and perpendicular (T5) transects were taken in pond P70, while vertical (depth, V2, V7) transects were taken in Vesicle Pond. Samples were stored frozen until shipment on ice to Germany.

Water chemistry parameters such as salinity (refractometer Atago, Kübler RH 312 ), conductivity (YSI Model 84 conductivity and salinity meter) and $\mathrm{pH}(\mathrm{pH}-$ meter 691, Metrohm, Herisau, Switzerland) were determined.

\subsection{Cyanobacterial taxonomy}

Cyanobacterial genera and species in the mats were determined using light microscopy (magnification $100-1000 \times$ ) after fixing the samples with Uthermoehl's solution (Schwoerbel, 1994). A representative sample was described using the classification system of Anagnostidis and Komarek (1988; Broady and Kibblewhite, 1991).

\subsection{Determination of organic content and extraction of cyanobacterial mat samples}

Since samples may vary widely in their organic content due to the large amount of sediment embedded in the mats, they were lyophilized and the organic content was determined by furnace incineration at $600^{\circ} \mathrm{C}$ for $14 \mathrm{~h}$. For toxin analysis, samples were extracted by sonication in $70 \%$ methanol for $60 \mathrm{~min}$ and subsequently centrifuged $\left(47,800 \mathrm{~g}, 4^{\circ} \mathrm{C}, 60 \mathrm{~min}\right)$. The extraction was performed twice, the supernatants pooled and rotary evaporated at $30^{\circ} \mathrm{C}$ (Rotavapor R-114, Büchi, Flawil, Switzerland, pump Vacuubrand, Wertheim, Germany). The extracts were solubilized with $100 \%$ methanol, dried under nitrogen and finally taken up in a defined volume of MilliQ water. Results were standardized to $200 \mathrm{mg}$ organic content. 


\subsection{Determination of toxin content}

In order to detect the presence of phosphatase inhibiting toxins such as the microcystins or nodularins, cyanobacterial mat extracts were tested in the protein phosphatase inhibition assay (PPIA; MacKintosh, 1993) and with high performance liquid chromatography (HPLC). PPIA was performed as described previously including an acid molybdate extraction step (MacKintosh, 1993). In short, phosphorylase $b$ was ${ }^{32} \mathrm{P}$-labeled with $\left[{ }^{32} \mathrm{P}\right] \mathrm{ATP}$ (kindly provided by $\mathrm{W}$. Hofer, University of Konstanz) using phosphorylase kinase. Extracts were preincubated with rape seed phosphatase (MacKintosh and Cohen, 1989) for $10 \mathrm{~min}$ and subsequently incubated with $\left[{ }^{32} \mathrm{P}\right]$ phosphorylase a for $5 \mathrm{~min}$ (all incubations at $30^{\circ} \mathrm{C}$ ). The reaction was stopped by addition of ice-cold $20 \%$ trichloroacetic acid and centrifugation. The supernatant containing free ${ }^{32} \mathrm{P}$ was extracted with acid molybdate, scintillation cocktail (Ready Safe, Beckman, Germany) was added and radioactivity counted in a scintillation counter (Beckman LS 6500, Beckman, Germany). Microcystin-LR (Calbiochem, Bad Soden, Germany) was used as a standard and results are expressed as percentage of an untreated control. The comparison of the inhibiting activities of the samples with the standard (microcystin-LR) allowed to semi-quantitatively determine the amounts of microcystin-LR-equivalents present in the samples. HPLC was performed on samples previously extracted by solid phase extraction through Isolute-C18 columns (International Sorbent Technology, UK; Lawton et al., 1994). External standards were prepared by mixing microcystin-LR and nodularin as well as microcystin-YR and microcystin-RR (Sigma, Deisenhofen, Germany or Calbiochem, Bad Soden, Germany). Standards and samples were analyzed in acetonitril-0.0135 $\mathrm{M}$ ammonium acetate $(27 \%: 73 \%)$ in a Beckman Autosampler 507 e, solvent module 125 with a UV detector module 166 using an Ultrasphere ODS column $(250 \times 4.6 \mathrm{~mm}, 5 \mu \mathrm{m}$; Beckman Instruments $\mathrm{GmbH}$, München, Germany). Peaks with a similar retention time to standards were "spiked" with a known amount of standard in order to further confirm the presence of the toxin.

\subsection{Isolation of trout hepatocytes and determination of cytotoxicity using the 3- (4,5-dimethylthiazol-2-yl)-2,5-diphenyl-tetrazolium bromide (MTT) and the trypan blue assays}

The presence of cytotoxic substances in the cyanobacterial mat extracts was determined in the 1998 and 1999 samples using the MTT test and the trypan blue dye exclusion test in trout hepatocytes (Borenfreund et al., 1988). Trout hepatocytes were isolated according to Ostrander et al. (1995) from rainbow trout (Oncorhynchus mykiss) obtained from a local hatchery. The livers were perfused with ice-cold HBSS containing $0.2 \mathrm{mM}$ EDTA, removed and following mechanical dissection digested with collagenase type IV (Sigma, Deisenhofen, Germany). Hepatocyte suspensions were plated in Primaria ${ }^{\mathrm{TM}}$ (Becton Dickinson, Heidelberg, Germany) multiwell plates after having been taken up in Eagle's MEM with Earle's salts containing $2 \mathrm{mM}$ glutamine, 0.1 M MEM non-essential 
amino acids, $26 \mathrm{mM} \mathrm{NaHCO} 3,1.317 \mathrm{~g} / 1 \mathrm{NaCl}$, antibiotics $(100,000 \mathrm{U} / 1$ penicillin $\mathrm{G}, \quad 0.1 \mathrm{~g} / 1$ streptomycin, $250 \mu \mathrm{g} / 1$ amphotericin $\mathrm{B}$; all Life Technologies, Eggenstein-Leopoldshafen, Germany), and $10 \%$ bovine calf serum (Sigma, Deisenhofen, Germany). Incubation with the cyanobacterial extracts was performed serum-free over $24 \mathrm{~h}$ at $18^{\circ} \mathrm{C}$. A positive control $\left(626 \mu \mathrm{M} \mathrm{CuSO}_{4}\right)$ was included. The MTT test is based on the formation of formazan from MTT by $\mathrm{NAD}(\mathrm{P}) \mathrm{H}$-dependent enzymes. After solubilization of formazan, the absorption can be detected at $550 \mathrm{~nm}$ in a microplate reader (SLT, Grödig, Austria). To exclude interference of the cyanobacterial extracts their absorption at $550 \mathrm{~nm}$ was subtracted. The trypan blue assay is based on the fact that only non-viable hepatocytes take up the dye.

\subsection{Statistics}

Outliers were determined using the extreme studentized deviate method (Barnett and Lewis, 1994).

\section{Results}

\subsection{Water chemistry}

Water chemistry parameters in the different sample ponds varied widely (Table 1). The estuary showed uniformly brackish water with a salinity between 5.7 and 9.7 parts per thousand (ppt) in 1998 and 1999, conductivity of 8.9$10.7 \mathrm{mS} / \mathrm{cm}$ and $\mathrm{pH}$ values between 6.3 and 7.6. Ponds in the undulating ice region, on the other hand, ranged from fresh water $(1.8 \mathrm{ppt}, 0.16 \mathrm{mS} / \mathrm{cm})$ to hypersaline (49 ppt, $55 \mathrm{mS} / \mathrm{cm}$ ) with $\mathrm{pH}$ values between 6.67 and 8.28. The temperature varied between frozen water to $5^{\circ} \mathrm{C}$.

\subsection{Taxonomy of cyanobacteria found in mats}

Cyanobacterial species found in the mats belonged mostly to the Oscillatoriales, although Nostoc sp. and Nodularia sp. were also frequently encountered. Anabaena antarctica (akinetes) was regularly but infrequently found. Oscillatoriales are usually grouped according to their trychome width: Oscillatoriales 1-1.5 $\mu \mathrm{m}$, Oscillatoriales 4-6 $\mathrm{m}$, Oscillatoriales 7-9 $\mu \mathrm{m}$. In our study the Oscillatoriales $1-1.5 \mu \mathrm{m}$ were represented by Phormidium deflexum (West and West), Leptolyngbia frigida (Fritsch) and possibly by Pseudoanabaena sp., Oscillatoriales 4-6 $\mu \mathrm{m}$ by $P$. pseudopriestleyi (West and West), P. autumnale (West and West), and P. murrayi (West and West), and Oscillatoriales 7-9 $\mu \mathrm{m}$ by $P$. koettlitzi (Fritsch) and $P$. subproboscideum (West and West). The cyanobacterial mats showed a great biodiversity often containing between five and eight species in one sample. This biodiversity was especially noticeable in the samples coming from brackish and hypersaline ponds (Fig. 4), whose 
cyanobacterial mat communities were mostly formed by Oscillatoriales up to $6 \mu \mathrm{m}$ in diameter and Nodularia sp., while Nostoc sp. was never encountered in the estuary or in saline ponds.

\subsection{Phosphatase inhibiting activity of cyanobacterial mat extracts}

In order to determine whether cyanobacteria from an extreme environment such as Antarctica also produce toxins inhibiting protein phosphatases, mat extracts were tested in the PPIA. The results show that almost all cyanobacterial mats tested, showed phosphatase inhibiting activity (Figs. 1-3). About half of the samples tested even inhibited the activity by more than $50 \%$ compared to controls. This can be quantified as $\geq 0.15 \mathrm{nM}$ microcystin-LR-equivalents using the standard curve obtained with microcystin-LR. The median value over the years $1997-1999$ was $0.2 \mathrm{nM}$.

It is also noticeable that phosphatase inhibiting toxin contents varied widely depending on the location of the sample site and on the water chemistry of the pond. The highest toxin contents could be found in the relatively brackish ponds

Table 1

Salinity, conductivity and $\mathrm{pH}$ in study ponds in the three collection areas ${ }^{\mathrm{a}}$

\begin{tabular}{|c|c|c|c|c|}
\hline Pond ${ }^{\mathrm{b}}$ & Sample number & Salinity (ppt) & Conductivity $(\mu \mathrm{S} / \mathrm{cm})$ & $\mathrm{pH}$ \\
\hline \multicolumn{5}{|l|}{ Around P70 } \\
\hline P70 & $13-15, \mathrm{~T} 5, \mathrm{H} 2, \mathrm{H} 4$ & $3.8^{\mathrm{c}} ; 2.6^{\mathrm{d}}$ & $4.28^{\mathrm{d}}$ & $9.58^{\mathrm{d}}$ \\
\hline Brack & $26-2,27$ & $12-14^{\mathrm{c}}, 10.5^{\mathrm{d}}$ & $15.8^{\mathrm{d}}$ & $7.1-8.0^{\mathrm{c}}$ \\
\hline \multicolumn{5}{|c|}{ Secondary mat collecting area } \\
\hline Ice Ridge Pond & 1 & 2.9 & 4.8 & nd \\
\hline Long pond & $2-4$ & $6.5-8^{\mathrm{c}}, 2.7^{\mathrm{d}}$ & $4.4^{\mathrm{d}}$ & $6.7-7.7^{\mathrm{c}}$ \\
\hline Small pond & $5-7$ & $1.5-2^{\mathrm{c}}, 0.2^{\mathrm{d}}$ & $0.52^{\mathrm{d}}$ & $7.3-7.8^{\mathrm{c}}$ \\
\hline Brackish pond & 8 & $6^{\mathrm{c}}, 5.2^{\mathrm{d}}$ & $8.36^{\mathrm{d}}$ & $7.2^{\mathrm{c}}$ \\
\hline L-shaped pond & $9-10$ & $3.8-4^{\mathrm{c}}, 9^{\mathrm{d}}$ & $1.66^{\mathrm{d}}$ & $6.5-6.9^{c}$ \\
\hline Lager pond & $11,38-39$ & $3-6^{\mathrm{c}}, 3.6^{\mathrm{d}}$ & $6.08^{\mathrm{d}}$ & $7.5-8.5^{\mathrm{c}}$ \\
\hline Small semi-dry pond & 12 & $\mathrm{nd}^{\mathrm{e}}$ & nd & nd \\
\hline Larger pond & $35-37$ & $0.1-0.25^{\mathrm{c}}, 0.8^{\mathrm{d}}$ & $1.54^{\mathrm{d}}$ & $8-8.3$ \\
\hline \multicolumn{5}{|l|}{ Bratina Island Estuary } \\
\hline Lagoon entrance & $17-18$ & $5^{\mathrm{c}}, 5.7^{\mathrm{d}}$ & 8.92 & $6.6-7.4^{\mathrm{c}}$ \\
\hline Vesicle Pond & 19 & $10.5^{\mathrm{c}}, 6.8^{\mathrm{d}}$ & $10.7^{\mathrm{d}}$ & $6.7^{\mathrm{c}}$ \\
\hline Vesicle Pond Jr. & $19 \mathrm{~A}$ & $10^{\mathrm{c}}, 6.8^{\mathrm{d}}$ & $10.7^{\mathrm{d}}$ & $9^{c}$ \\
\hline Pancreas Pond & $20,20-2$ & $10^{\mathrm{c}}, 6.8^{\mathrm{d}}$ & $10.7^{\mathrm{d}}$ & $6.7^{\mathrm{c}}$ \\
\hline Lagoon channel & $21-23$ & $10^{\mathrm{c}}, 6.8^{\mathrm{d}}$ & $10.7^{\mathrm{d}}$ & $6.2-6.4^{c}$ \\
\hline Near Pancreas Pond & 24 & $6.5^{\mathrm{c}}, 6.8^{\mathrm{d}}$ & $10.7^{\mathrm{d}}$ & nd \\
\hline Lagoon & 40 & $7^{\mathrm{c}}$ & nd & $7.7^{\mathrm{c}}$ \\
\hline Channel near Vesicle Pond & $\mathrm{V} 2, \mathrm{~V} 7$ & $9.5^{\mathrm{c}}$ & nd & $6.7^{\mathrm{c}}$ \\
\hline
\end{tabular}

${ }^{\text {a }}$ Sample numbers are also shown for reference.

${ }^{\mathrm{b}}$ Unofficial names of study ponds.

${ }^{\mathrm{c}} 1998$.

d 1999.

${ }^{\mathrm{e}}$ nd: not determined. 
of the sample site "around P70" (see sample 26 from Brack pond showing strong phosphatase inhibiting activity in 1998 and 1999; Figs. 1 and 4) and in samples from the brackish "Bratina Island Estuary" (Fig. 3). It is at this moment very difficult to specifically state which Antarctic cyanobacterial species have the ability to synthesize phosphatase inhibiting toxins and which species actually produce them under these environmental conditions. What can definitely be stated is that Nostoc sp. produced phosphatase inhibiting toxins. This can be demonstrated with sample 6, in which Nostoc sp. was found exclusively (1997) or represented the dominating species (1999; Fig. 2). However, Nostoc sp. did not synthesize high concentrations of these toxins when compared to other mat samples in which Oscillatoriales species or Nodularia sp. were present. Sample 26, for example, consistently showing high toxin concentrations, had a large species diversity in which representatives of all Oscillatoriales groups as well as Nodularia sp. and Nostoc sp. have been identified (Figs. 1 and 4). This species diversity could also be observed in freshwater mat sample 9, but only the presence of $P$. pseudopriestleyi in 1999 led to a high phosphatase inhibiting activity (Fig. 5). As sample 36 however illustrates, a high species diversity does not necessarily lead to a high phosphatase inhibitory activity (Fig. 6).

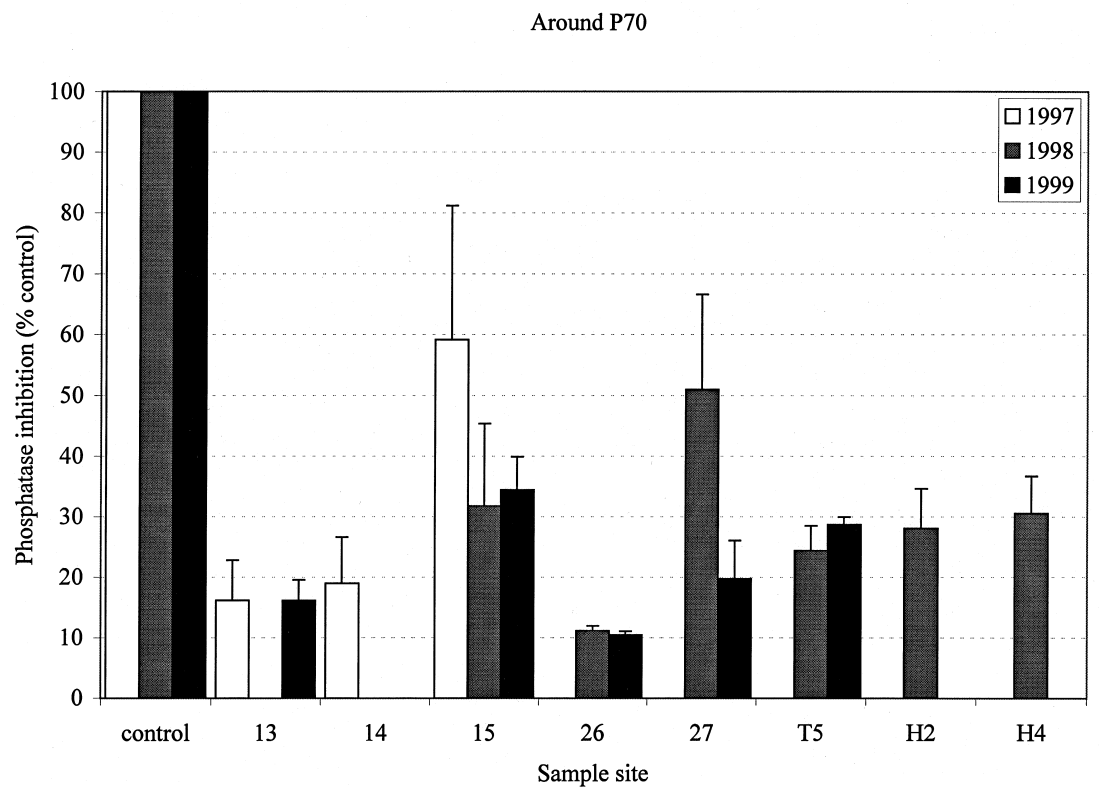

Fig. 1. Phosphatase inhibitory activity of cyanobacterial mat extracts from sample sites "Around P70". Shown are the results of three consecutive collection years (1997-1999) expressed as percent controls of triplicate determinations. 


\subsection{HPLC analysis}

In order to further identify the phosphatase inhibiting toxins, samples were analyzed by HPLC using comparison of retention times to standards and cochromatography. Examples (samples 8 and 21) are shown in Figs. 7 (a),(b) and 8. A comparison of both retention time and cochromatography showed the putative presence of both nodularin and microcystin-LR in sample 8, while sample 21 indicated the presence of nodularin.

\subsection{Cytotoxic activity of cyanobacterial mat extracts}

In addition to phosphatase inhibiting toxins Antarctic cyanobacteria also produced substances that were cytotoxic in trout hepatocytes (Figs. 9 and 10). This cytotoxic activity appeared to be unrelated to the mechanism leading to protein phosphatase inhibition. Indeed, some extracts (e.g. sample 26) having a very high inhibitory activity had no cytotoxic activity determined via MTT (Fig. 9), while all extracts demonstrating high cytotoxicity also exhibited $\geq 50 \%$ phosphatase inhibition capacity. Another example demonstrating this dissociation between phosphatase inhibitory activity and effect on cell viability is sample 19, which in 1998 completely inhibited MTT metabolism in hepatocytes while no such effect could be seen in 1999. Phosphatase inhibitory activity, however, remained at

Secondary Mat Collecting Area

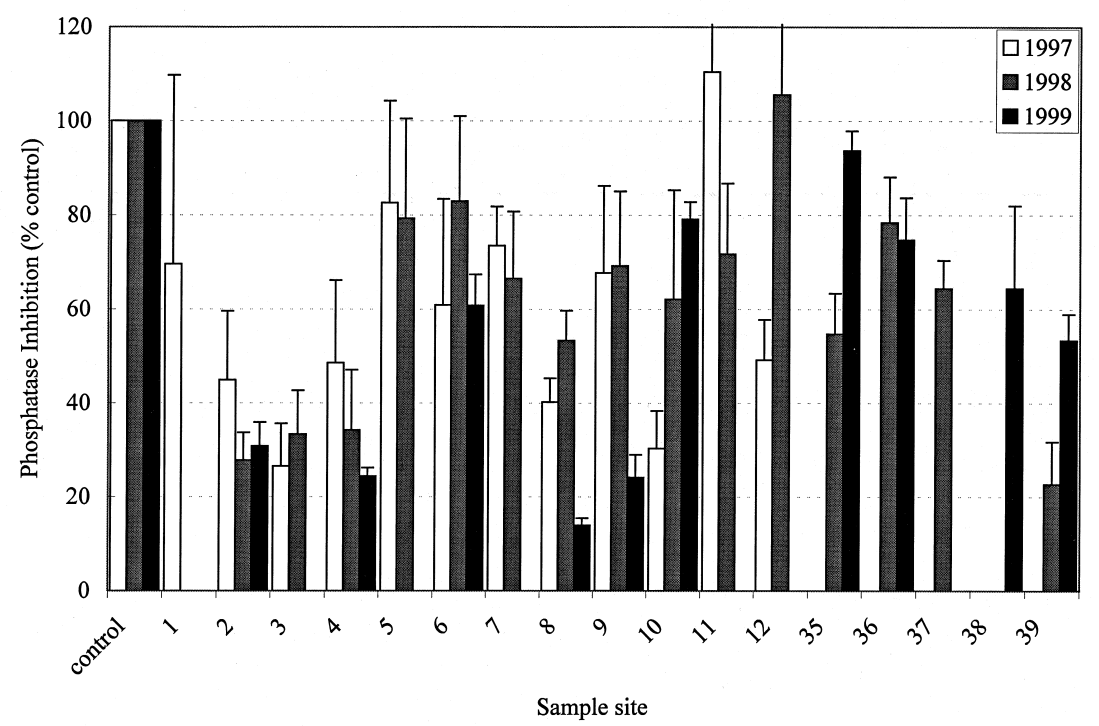

Fig. 2. Phosphatase inhibitory activity of cyanobacterial mat extracts from sample sites "Secondary Mat Collecting Area". Shown are the results of three consecutive collection years (1997-1999) expressed as percent controls of triplicate determinations. 
the same level $(40 \%$ of control) in both years. Cytotoxic activity of the cyanobacterial extracts was also tested by trypan blue assay, an assay testing the "leakiness" of the cells. The results show that a number of extracts significantly decreased cell viability in this assay (Fig. 10). Furthermore, some samples inhibiting MTT activity showed no effect in trypan blue dye exclusion and vice versa.

\section{Discussion}

Toxic cyanobacterial species or strains have mainly been described from populated areas in temperate or tropical regions (Carmichael et al., 1988a, 1988b; Sivonen et al., 1989, 1990; Mez et al., 1996; Ueno et al., 1996b). This is the first description of toxin production in cyanobacteria from polar regions. These cyanobacteria form thick benthic mats in ponds on the McMurdo Ice Shelf and constitute a large part of the biomass. The variation in salinity, conductivity, $\mathrm{pH}$ and temperature found in the sample sites is characteristic for these ponds (Vincent, 1988; Howard-Williams et al., 1990; Hawes et al., 1993). The cyanobacterial mats vary in species composition depending apparently on these ecological factors, since saline and hypersaline ponds promote greater biodiversity. Oscillatoriales sensu Anagnostidis and Komarek (1988) could be detected in

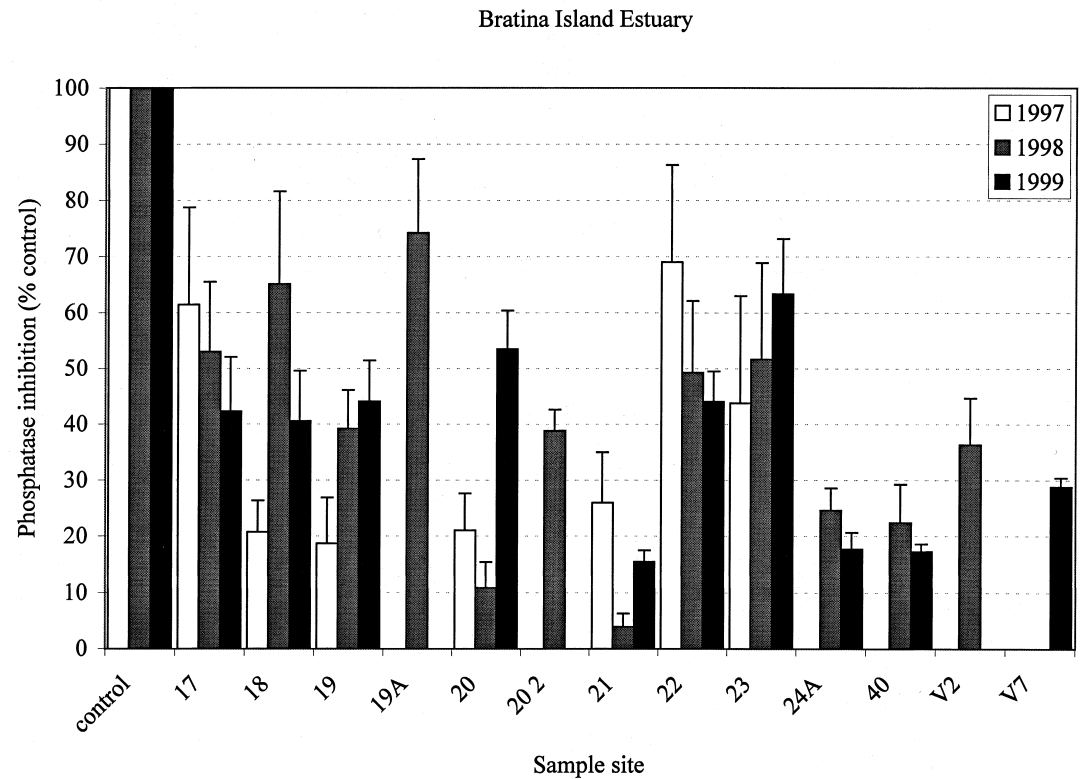

Fig. 3. Phosphatase inhibitory activity of cyanobacterial mat extracts from sample sites "Bratina Island Estuary". Shown are the results of three consecutive collection years (1997-1999) expressed as percent controls of triplicate determinations. 
almost all of the ponds including the hypersaline ones. Nodularia sp. and Anabaena sp. could also be detected quite regularly, while Nostoc sp. was restricted to freshwater ponds. Up to nine different cyanobacterial species could be identified in one mat sample using morphological methods. One has to keep in mind, though, that the cyanobacterial species were identified on the basis of trychome width, presence or absence of a calyptra, number of trychomes in a sheath and other morphological characteristics (Broady and Kibblewhite, 1991). These morphological characteristics, however, can change under different environmental conditions ("ecophenes") giving the false impression of varying species diversity. In the absence of a specific and reliable molecular taxonomic method for identification at the species level, species identification must therefore remain descriptive (Muyzer et al., 1993; Nübel et al., 1997, 1999).

In order to detect cyanobacterial toxins, the phosphatase inhibition assay and HPLC analysis was used. Approximately half of the samples tested over the three study years inhibited phosphatase activity by more than $50 \%$, corresponding to $\geq 0.15 \mathrm{nM}$ microcystin-LR equivalents. This assay may however also detect other compounds besides microcystins and nodularins, such as okadaic acid or calyculin

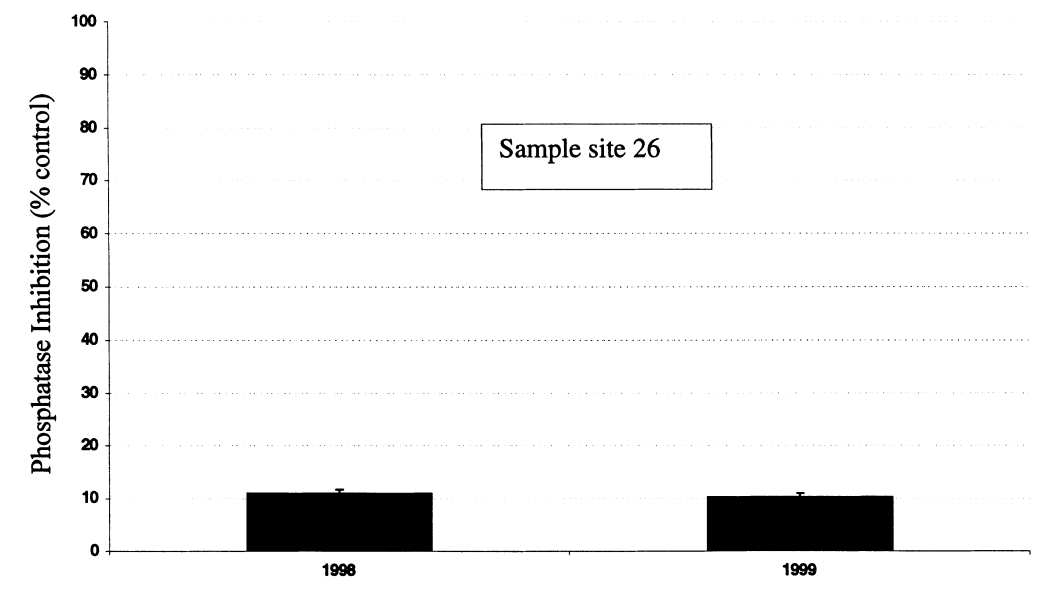

\begin{tabular}{|lcc|}
\hline Species & $\mathbf{1 9 9 8}$ & $\mathbf{1 9 9 9}$ \\
Trichomes $<1 \mu \mathrm{m}$ & 10 & $\mathrm{np}$ \\
Oscillatoriales $1-1.5 \mu \mathrm{m}$ & 8 & 29 \\
$\quad$ P. deflexum & 7 & \\
Oscillatoriales $4-6 \mu \mathrm{m}$ & 15 & 56 \\
P. pseudopriestleyi & 15 & 10 \\
Oscillatoriales $7-9 \mu \mathrm{m}$ & 15 & 5 \\
Nodularia sp. & 15 & $\mathrm{np}$ \\
Nostoc sp. & 35 & \\
\hline
\end{tabular}

Fig. 4. Phosphatase inhibitory activity of cyanobacterial mat extract from sample site 26 (Brack pond) and corresponding semi-quantitative taxonomic determinations of the collecting years 1998 and 1999 . Phosphatase inhibition results are expressed as percent controls of triplicate determinations. 
A (MacKintosh, 1993), although it is unlikely that they were present in the Antarctic samples tested. The relatively high inhibitory activity found in the samples therefore can be attributed to the presence of cyclic peptide toxins. This was further confirmed using HPLC which showed peaks displaying similar characteristics of both nodularin and microcystin-LR standards. The ecological role of cyclic peptide toxins, such as the microcystins and nodularins, has not been conclusively determined yet. It has, for example, been suggested that these toxins inhibit the growth of diatoms (Keating, 1978) and of other cyanobacterial species (Bagchi et al., 1990). Contrary to this suggestion is the recent finding that cyanobacterial phosphatases are insensitive to microcystins (Shi et al., 1999). Furthermore, the present study demonstrated the highest phosphatase inhibiting activity in cyanobacterial mats exhibiting a high species diversity. The predominance of cyanobacteria and the overt lack of large phytoplankton communities may largely result from environmental factors unfavorable to phytoplankton growth such as lack of nitrogen and/or temperature limitation

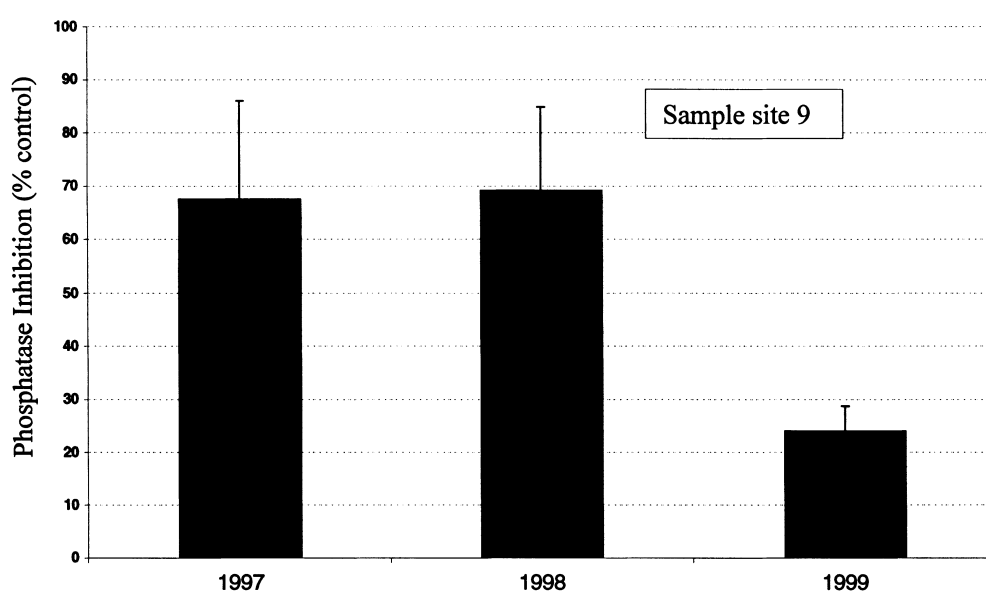

\begin{tabular}{|c|c|c|c|}
\hline Species & 1997 & 1998 & 1999 \\
\hline Trichomes $<1 \mu \mathrm{m}$ & nd & 40 & 42 \\
\hline Oscillatoriales $1-1.5 \mu \mathrm{m}$ & 60 & 10 & \\
\hline$P$. deflexum & & 10 & 7 \\
\hline L. frigida & & 10 & $\mathrm{np}$ \\
\hline Oscillatoriales $4-6 \mu \mathrm{m}$ & 20 & & \\
\hline P. autumnale & & 10 & $\mathrm{np}$ \\
\hline P. pseudopristleyi & & np & 41 \\
\hline Oscillatoriales $7-9 \mu \mathrm{m}$ & $\mathrm{np}$ & & \\
\hline P. koettlitzi & & 10 & 7 \\
\hline Nodularia sp. & 20 & np & 3 \\
\hline Nostoc sp. & $\mathrm{np}$ & 10 & $\mathrm{np}$ \\
\hline
\end{tabular}

Fig. 5. Phosphatase inhibitory activity of cyanobacterial mat extract from sample site 9 (a freshwater pond in the "Secondary Mat Collecting Area") and corresponding semi-quantitative taxonomic determinations of the collecting years 1997, 1998 and 1999. Phosphatase inhibition results are expressed as percent controls of triplicate determinations. 
(Hawes et al., 1993) and not from the presence of inhibitory toxins. A second potential ecological role of these toxins is protection against grazers. The environmental conditions in the ponds on the Ice Shelf do not support macroinvertebrate grazers, another reason for the great accumulation of these benthic mats (Hawes et al., 1993). Heterotrophic flagellates, rotifers, nematodes and tardigrades are present, however, on and within the mats. Studies investigating effects of cyanobacterial toxins on temperate counterparts of these taxa show equivocal results (Gilbert, 1994; Christoffersen, 1996). Interestingly, mats showing a high cyanobacterial species diversity also support microzooplankton communities (personal observations). Studies on the effects of cyanobacterial toxins in Antarctic rotifer and tardigrade species are yet lacking. The observed temporal variation in species composition and toxin content over the three sampling years may be due to variations in abiotic factors, e.g. meteorological conditions on the Ice Shelf or changes in water chemistry. It is, for example, known that conductivity usually increases over the course of January due to evaporative concentration, while nutrients normally remain stable (Hawes et al., 1993). The between season variability in nutrient concentrations has been

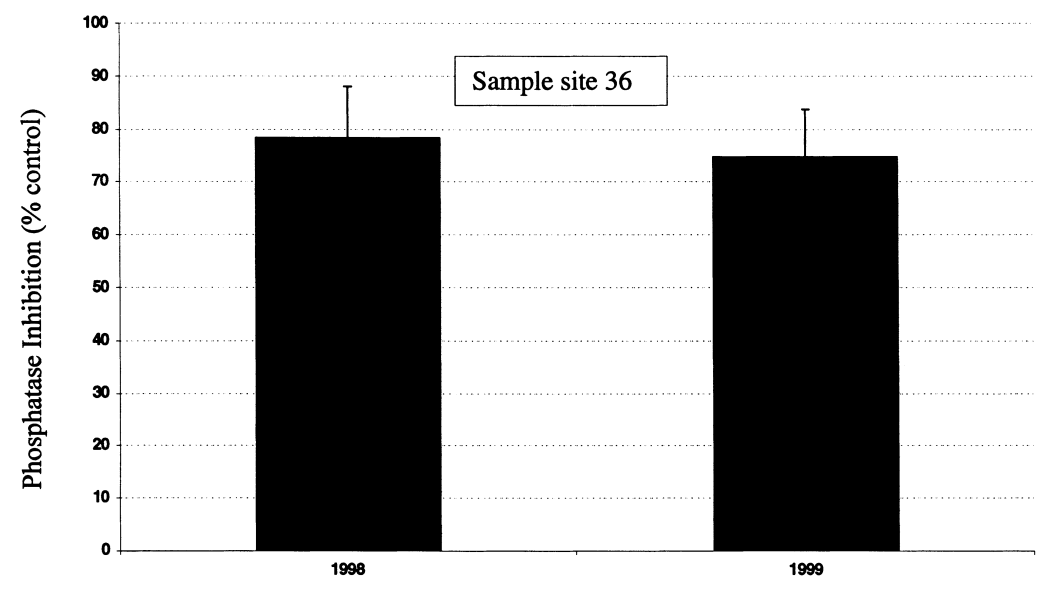

\begin{tabular}{|lcc|}
\hline Species & $\mathbf{1 9 9 8}$ & 1999 \\
Trichomes $<1 \mu \mathrm{m}$ & $\mathrm{np}$ & 30 \\
Oscillatoriales $1-1.5 \mu \mathrm{m}$ & $\mathrm{np}$ & 30 \\
$\quad \begin{array}{l}\text { P. deflexum } \\
\text { Oscillatoriales } 4-6 \mu \mathrm{m}\end{array}$ & 48 & 30 \\
Oscillatoriales $7-9 \mu \mathrm{m}$ & 4 & $\mathrm{np}$ \\
Nodularia sp. & $\mathrm{np}$ & 10 \\
Nostoc sp. & 48 & $\mathrm{np}$ \\
\hline
\end{tabular}

Fig. 6. Phosphatase inhibitory activity of cyanobacterial mat extract from sample site 36 (a freshwater pond in the "Secondary Mat Collecting Area") and corresponding semi-quantitative taxonomic determinations of the collecting years 1998 and 1999. Phosphatase inhibition results are expressed as percent controls of triplicate determinations. 
shown to be relatively high for the freshwater ponds but stable for those with a conductivity over $2000 \mu \mathrm{S} / \mathrm{cm}$ (Hawes et al., 1993). Variability in species composition of the cyanobacterial mats may also be due to mats being blown by wind into other ponds or due to movement of cyanobacteria through the mats as it is known for the Oscillatoriales.
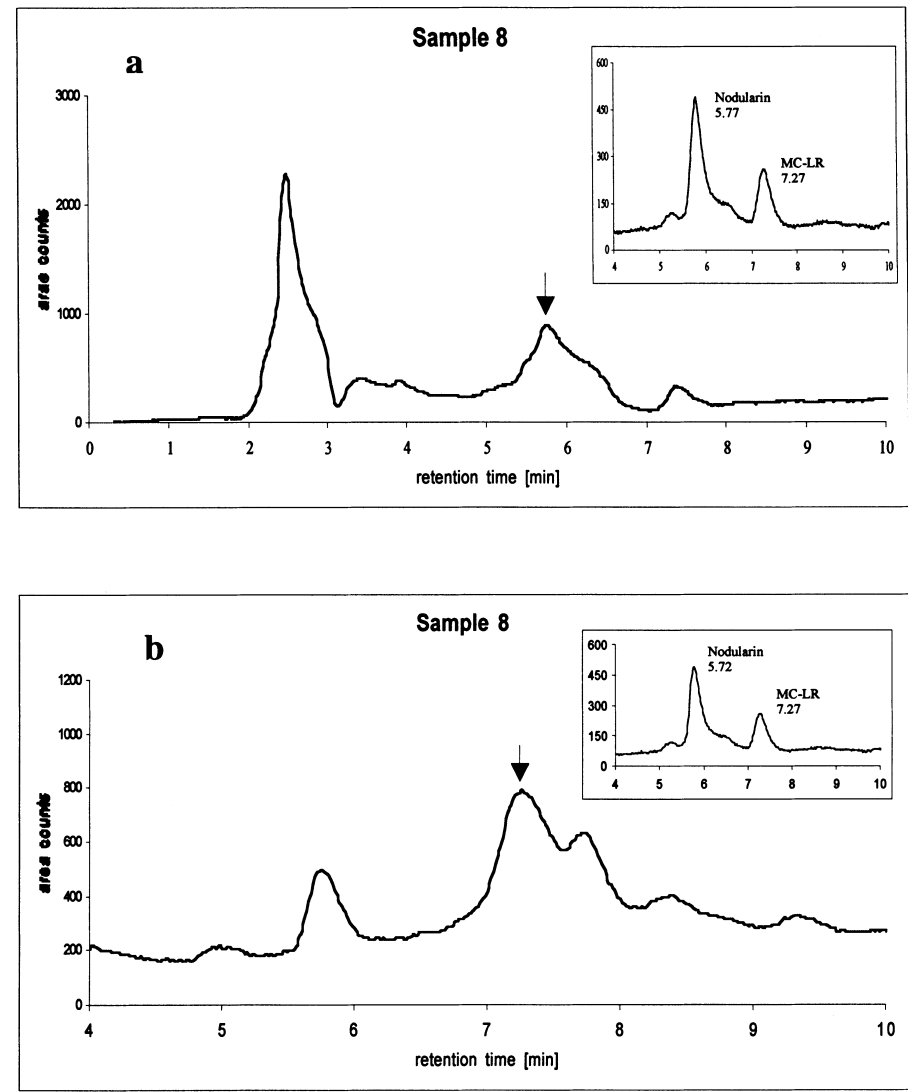

Retention time (min) Peak height Peak area

$\begin{array}{llccc}\text { a } & \text { Nodularin } & 5.77 & 400 & 8831 \\ & \text { Sample 21 + 25 ng nodularin } & 5.75 & 680 & 34810 \\ & & & & \\ \text { b } & \text { MC-LR (25 ng) } & 7.27 & 180 & 3330 \\ & \text { Sample 21 + 25 ng MC-LR } & 7.25 & 500 & 14650\end{array}$

Fig. 7. (a, b) HPLC chromatogram of extract of mat sample 8 (1999) spiked with either $25 \mathrm{ng}$ nodularin (a) or with $25 \mathrm{ng}$ microcystin-LR (b). Shown is also a comparison of retention times, peak height and peak area. 

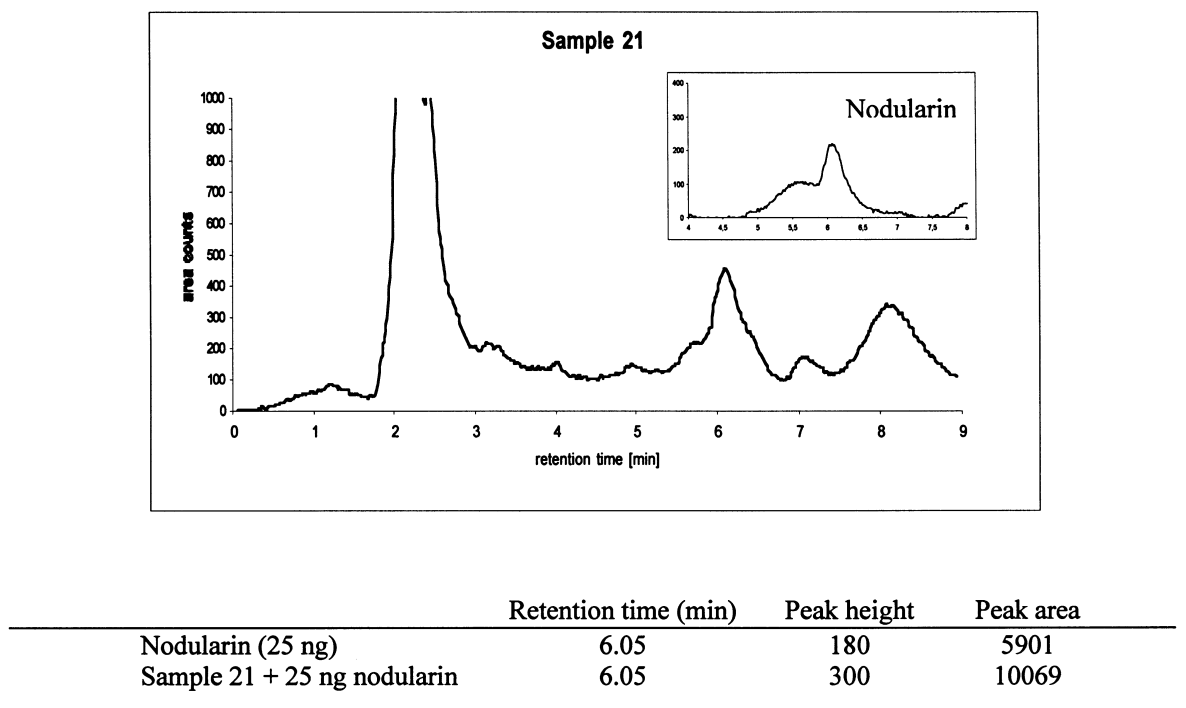

Fig. 8. HPLC chromatogram of extract of mat sample 21 (1999) spiked with 25 ng nodularin. Shown is also a comparison of retention times, peak height and peak area.

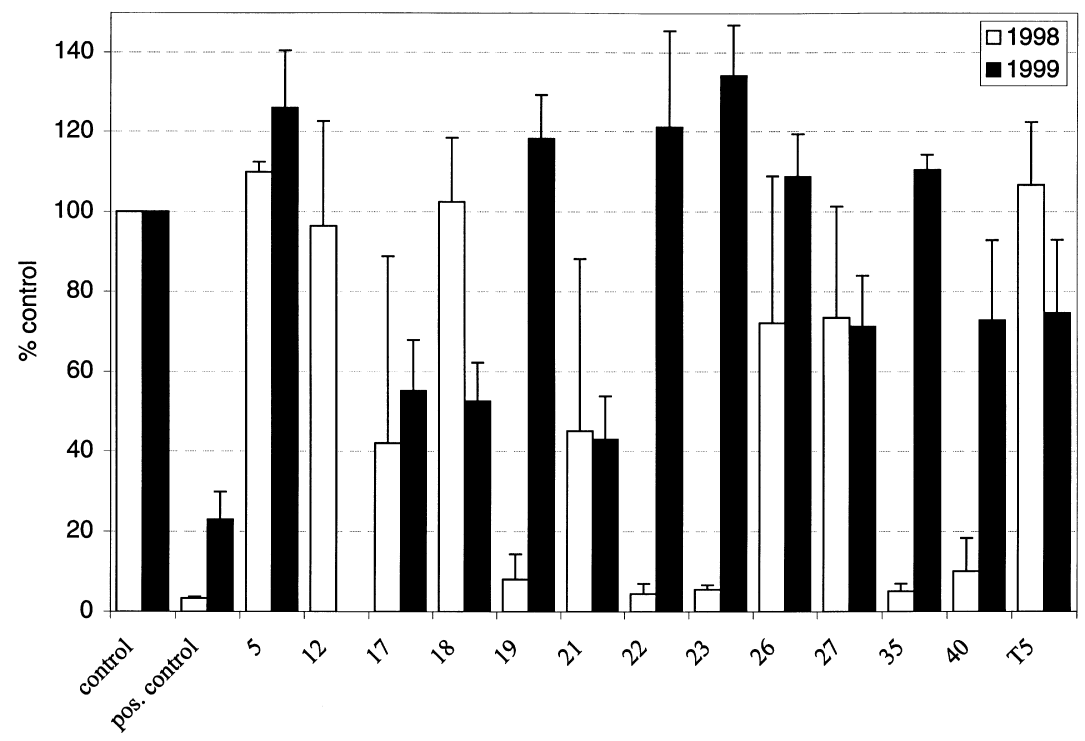

Sample site

Fig. 9. Cytotoxic activity of representative cyanobacterial mat extracts determined by MTT assay in trout hepatocytes. Shown are the results of collecting years 1998 and 1999 of three to four replicate determinations. 
The compound(s) responsible for the observed protein phosphatase independent cytotoxicity, i.e. determined via MTT and trypan blue, is at present unknown. However, a likely candidate may be scytonemin A, a pigment present in these cyanobacterial mats (Howard-Williams and Hawes, 1995). Scytonemin A was shown to possess calcium-antagonistic activity (Moore et al., 1988), thus having effects on cellular calcium homeostasis. Other secondary metabolites with cytotoxic activity have been described from the genus Scytonema, e.g. scytophycin $\mathrm{A}$ and $\mathrm{B}$, macrolides showing cytotoxic and growth inhibitory activity in leukemia cells and in mouse lung carcinomas (Moore et al., 1986). Phormidium, Oscillatoria and Lyngbya species have also been shown to produce compounds with antitumor activity (Moore et al., 1988).

In this study it was shown that benthic cyanobacterial mats from Antarctic meltwater ponds produce phosphatase inhibiting and cytotoxic activity. These relatively "simple" pond ecosystems offer the opportunity to study the functional and ecological role of the toxins. Species identification of Antarctic cyanobacteria is currently based on morphological characterization ("morphotypes"; Broady and Kibblewhite, 1991) and while culture of these strains is possible (Broady et al., 1984), toxic properties may be lost upon culture. It is therefore difficult to ascribe the production of toxins to specific species. The development of probes for the identification of cyanobacterial species and for the detection of genes responsible for toxin synthesis (Muyzer et al., 1993; Neilan, 1996; Nübel et al., 1997, 1999;

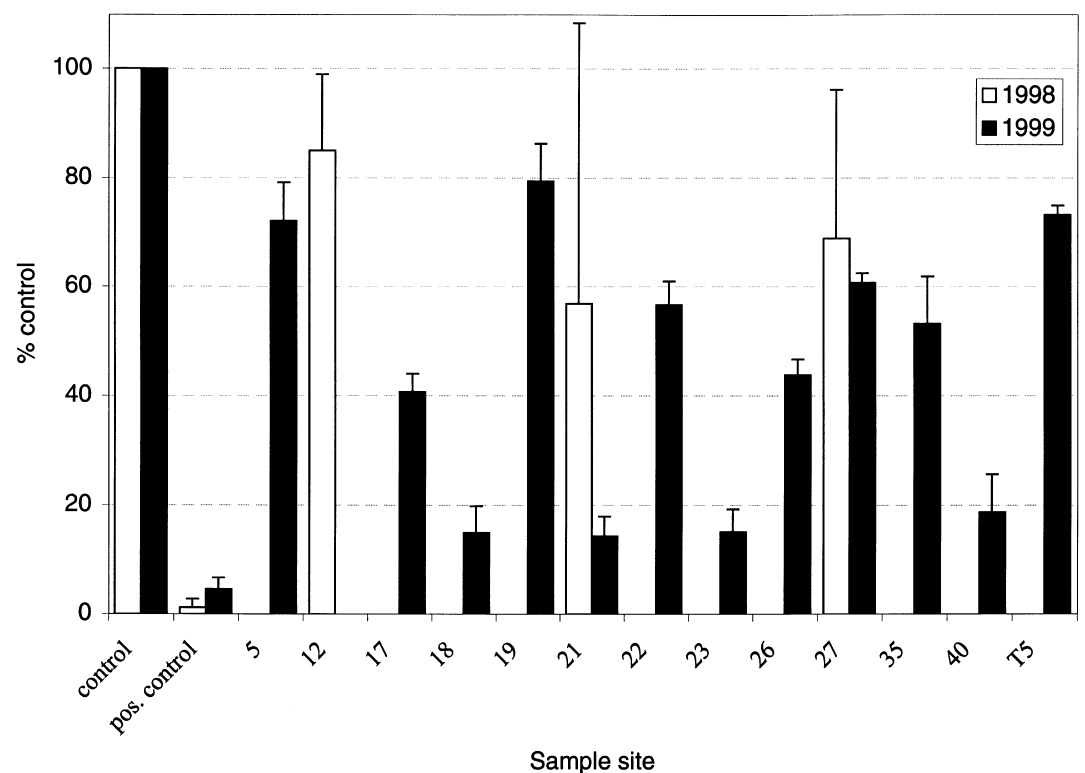

Fig. 10. Cytotoxic activity of representative cyanobacterial mat extracts determined by trypan blue dye exclusion test in trout hepatocytes. Shown are the results of collecting years 1998 and 1999 of three to four replicate determinations. 
Neilan et al., 1999) in the near future should help to identify toxic cyanobacteria strains in the diverse communities of Antarctica as well as to elucidate their role in those ecosystems.

\section{Acknowledgements}

We thank Rod Asher (Cawthron Institute, Nelson, New Zealand) for putting great efforts in collecting the samples on Bratina Island. We also gratefully acknowledge Paul Broady (University of Canterbury, Christchurch, New Zealand) for his expert assistance with cyanobacteria identifications. This work was in part funded by Contract C01601 ("Antarctic Aquatic Ecosystems") of the NZ Foundation for Research, Science and Technology, and logistic support was provided by Antarctica New Zealand. We also thank the National Science Foundation and the US Antarctic Program for making a visit of B.H. to Bratina Island possible.

\section{References}

Anagnostidis, K., Komarek, J., 1988. Modern approach to the classification system of cyanophytes; 3 — Oscillatoriales, Archiv. Hydrobiol. 327-472.

Bagchi, S., Palod, A., Chauhan, V., 1990. Algicidal properties of a bloom-forming blue-green alga, Oscillatoria sp. J. Basic. Microbiol. 30, 21-29.

Barnett, V., Lewis, T., 1994. Outliers in Statistical Data. Wiley, New York

Borenfreund, E., Babich, H., Martin-Alguacil, N., 1988. Comparisons of two in vitro cytotoxicity assays - the neutral red (NR) and tetrazolium MTT tests. Toxic. In Vitro 2, 1-6.

Broady, P.A., Kibblewhite, A.L., 1991. Morphological characterization of Oscillatoriales (Cyanobacteria) from Ross Island and southern Victoria Land, Antarctica. Antarc. Sci. 3, 35-45.

Broady, P.A., Garrick, R., Anderson, G., 1984. Culture studies on the morphology of ten strains of antarctic Oscillatoriaceae (cyanobacteria). Polar Biol. 2, 233-244.

Carmichael, W.W. 1997. The cyanotoxins. In: Advances in Botanical Research. Department of Biological Sciences Ohio, USA, pp. 211-256.

Carmichael, W.W., Eschedor, J.T., Patterson, G.M.L., Moore, R.E., 1988a. Toxicity and partial structure of a hepatotoxic peptide produced by the cyanobacterium Nodularia spumigena Mertens emend. L 575 from New Zealand. Appl. Environ. Microbiol. 54, 2257-2263.

Carmichael, W.W., He, J.-W., Eschedor, J., He, Z.-R., Juan, Y.-M., 1988b. Partial structural determination of hepatotoxic peptides from Microcystis aeruginosa (cyanobacterium) collected in ponds of Central China. Toxicon 26, 1213-1217.

Christoffersen, K., 1996. Ecological implications of cyanobacterial toxins in aquatic food webs. Phycologia 35, 42-50.

Eriksson, J.E., Toivola, D., Meriluoto, J.A.O., Karaki, H., Han, Y.-G., Hartshorne, D., 1990. Hepatocyte deformation induced by cyanobacterial toxins reflects inhibition of protein phosphatases. Biochem. Biophys. Res. Commun. 173, 1347-1353.

Gilbert, J.J., 1994. Susceptibility of planktonic rotifers to a toxic strain of Anabaena flos-aquae. Limnol. Oceanogr. 39, 1286-1297.

Hawes, I., Howard-Williams, C., Pridmore, R., 1993. Environmental control of microbial biomass in the ponds of the McMurdo Ice Shelf, Antarctica. Arch. Hydrobiol. 127, 271-287.

Howard-Williams, C., Hawes, I., 1995. Inland waters of Antarctica: where cyanobacteria rule supreme. NIWA Water \& Atmosphere 3, 22-23. 
Howard-Williams, C., Pridmore, R., Downes, M., Vincent, W., 1989. Microbial biomass, photosynthesis and chlorophyll a related pigments in the ponds of the McMurdo Ice Shelf, Antarctica. Antarc. Sci. 1, 125-131.

Howard-Williams, C., Pridmore, R., Broady, P., Vincent, W. 1990. Environmental and biological variability in the McMurdo Ice Shelf ecosystem. In: Kerry, K., Hempel, G. (Eds.), Antarctic Ecosystems. Ecological Change and Conservation. Springer, Berlin.

Humpage, A., Rositano, J., Bretag, A., Brown, R., Baker, P., Nicholson, B., Steffensen, D., 1994. Paralytic shellfish poisons from Australian cyanobacterial blooms. Aust. J. Mar. Freshwat. Res. 45, 761-771.

Keating, K., 1978. Blue-green algal inhibition of diatom growth: transition from mesotrophic to eutrophic community structure. Science 199, 971-973.

Lawton, L.A., Edwards, C., Codd, G.A., 1994. Extraction and high-performance liquidchromatographic method for the determination of microcystins in raw and treated waters. Analyst $119,1525-1530$.

MacKintosh, C. 1993. Assay and purification of protein (serine/threonine) phosphatases. In: Hardie, D.G. (Ed.), Protein Phosphorylation: A Practical Approach. Oxford University Press, Oxford, pp. 197-229.

MacKintosh, C., Cohen, P., 1989. Identification of high levels of type 1 and type 2A protein phosphatases in higher plants. Biochem. J. 262, 335-339.

MacKintosh, C., Beattie, K.A., Klumpp, S., Cohen, P., Codd, G.A., 1990. Cyanobacterial microcystin$\mathrm{LR}$ is a potent and specific inhibitor of protein phosphatases 1 and $2 \mathrm{~A}$ from both mammals and higher plants. FEBS Lett. 264, 187-192.

Mez, K., Hanselmann, K., Naegeli, H., Preisig, H., 1996. Protein phosphatase-inhibiting activity in cyanobacteria from alpine lakes in Switzerland. Phycologia 36, 133-139.

Moore, R.E., Patterson, G.M.L., Mynderse, J.S., Barchi, J., Norton, T.R., Furusawa, E., Furusawa, S., 1986. Toxins from cyanophytes belonging to the scytonemataceae. Pure Appl. Chem. 58, 263-271.

Moore, R.E., Patterson, G.M.L., Carmichael, W.W. 1988. New pharmaceuticals from cultured bluegreen algae. In: Fautin, D.G. (Ed.), Biomedical Importance of Marine Organisms. California Academy of Sciences, San Francisco, CA, pp. 143-150.

Muyzer, G., De Waal, E., Uitterlinden, A., 1993. Profiling of complex microbial populations by denaturing gradient gel electrophoresis analysis of polymerase chain reaction-amplified genes coding for 16S rRNA. Appl. Environ. Microbiol. 59, 695-700.

Neilan, B., 1996. Detection and identification of cyanobacteria associated with toxic blooms: DNA amplification protocols. Phycologia 35, 147-155.

Neilan, B.A., Dittmann, E., Rouhiainen, L., Bass, R.A., Schaub, V., Sivonen, K., Börner, T., 1999. Nonribosomal peptide synthesis and toxigenicity of cyanobacteria. J. Bacteriol. 181, 4089-4097.

Nübel, U., Garcia-Pichel, F., Muyzer, G., 1997. PCR primers to amplify rRNA genes from cyanobacteria. Appl. Environ. Microbiol. 63, 3327-3332.

Nübel, U., Garcia-Pichel, F., Kühl, M., Muyzer, G., 1999. Quantifying microbial diversity: morphotypes, 16S rRNA genes, and carotenoids of oxygenic phototrophs in microbial mats. Appl. Environ. Microbiol. 65, 422-430.

Ostrander, G., Blair, J., Stark, B., Marley, G., Bales, W., Veltri, R., Hinton, D., Okihiro, M., Ortego, L., Hawkins, W., 1995. Long-term primary culture of epithelial cells from rainbow trout (Oncorhynchus mykiss) liver. In Vitro Cell. Develop. Biol. 31, 367-378.

Rinehart, K.L., Namikoshi, M., Choi, B.W., 1994. Structure and biosynthesis of toxins from blue-green algae (cyanobacteria). J. Appl. Phycol. 6, 159-176.

Schwoerbel, J., 1994. Methoden der Hydrobiologie - Süßwasserbiologie. Gustav Fischer, Stuttgart

Shi, L., Carmichael, W.W., Kennelly, P.J., 1999. Cyanobacterial PPP family protein phosphatases possess multifunctional capabilities and are resistant to microcystin-LR. J. Biol. Chem. 274, 1003910046.

Sivonen, K., Kononen, K., Carmichael, W.W., Dahlem, A.M., Rinehart, K.L., Kiviranta, J., Niemelä, S.I., 1989. Occurrence of the hepatotoxic cyanobacterium Nodularia spumigena in the Baltic Sea and structure of the toxin. Appl. Environ. Microbiol. 55, 1990-1995. 
Sivonen, K., Niemelä, S.I., Niemi, R.M., Lepistö, L., Luoma, T.H., Räsänen, L.A., 1990. Toxic cyanobacteria (blue-green) algae in Finnish fresh and coastal waters. Hydrobiologia 190, 267-275.

Skulberg, O.M., Codd, G.A., Carmichael, W.W., 1984. Toxic blue-green algal blooms in Europe: a growing problem. Ambio 13, 244-247.

Ueno, Y., Nagata, S., Tsutsumi, T., Hasegawa, A., Watanabe, M.F., Park, H.-D., Chen, G.-C., Chen, G., Yu, S.-Z., 1996a. Detection of microcystins, a blue-green algal hepatotoxin, in drinking water sampled in Haimen and Fusui, endemic areas of primary liver cancer in China, by highly sensitive immunoassay. Carcinogenesis 17, 1317-1321.

Ueno, Y., Nagata, S., Tsutsumi, T., Hasegawa, A., Yoshida, F., Suttajit, M., Mebs, D., Pütsch, M., Vasconcelos, V., 1996b. Survey of microcystins in environmental water by a highly sensitive immunoassay based on monoclonal antibody. Nat. Toxins 4, 271-276.

Vincent, W., 1988. Microbial Ecosystems of Antarctica. Cambridge University Press, Cambridge.

Vincent, W., James, M., 1996. Biodiversity in extreme aquatic environments: lakes, ponds and streams of the Ross Sea, Antarctica. Biodiversity and Conservation 5, 1451-1471. 